\title{
TWO-DIMENSIONAL STOKES FLOW IN A SEMICIRCLE
}

\author{
V. V. M E L E S K O, A. M. G O M I L K O \\ Institute of Hydromechanics National Academy of Sciences, Kiev, Ukraine \\ Received 11.11 .98
}

\begin{abstract}
Построено точное решение вадачи о двумерном течении Стокса в полукруге, вызванное равномерным движением круговой или прямолинейной границы. Приведены контурные линии тока и типичное распределение скорости.

Побудовано точний розв'язок задачі про двовимірну течію Стокса у напівкрузі, яка зумовлена рівномірним рухом кругової або прямолінійної границі. Наведені контурні лінії тока та типовий ровподіл швидкості.

The exact analytical solution for the two-dimensional Stokes flow in a semicircle due to uniformly moving circular or straight boundary is obtained. The contour streamline pattern and a typical velocity distribution are shown.
\end{abstract}

\section{INTRODUCTION}

Two-dimensional fluid motions in which inertia forces are negligible compared to viscous forces (creeping or Stokes flows) have been widely studied. The linear form of the governing biharmonic equation yield, in many cases, closed-form solutions for flows in some canonical domains. On the other hand, there exists only an approximate solution $[5,6]$ for a problem of motion in a semicircle induced by a uniform tangential velocity at a circular boundary. In the present note we provide the exact analytical solution for this problem.

The method of solution is based on a usage of the bipolar coordinate system. This system for the twodimensional biharmonic equation was employed early for exact solutions of problems for both Stokes flow $[3,4,8]$ and elastic stresses $[2,7]$ in domains enclosed by eccentric cylinders.

\section{STATEMENT OF THE PROBLEM}

Consider Stokes flow inside a semicircle $0 \leq r \leq a$, $0<\theta<\pi$ generated by either a constant tangential velocity $V$ applied at the curved part of the boundary, or a constant tangential velocity $U$ applied at the plane part of the boundary. The rest of the boundary remains unmovable.

The velocity field is given in terms of the stream function $\psi(r, \theta)$ by

$$
u_{r}=\frac{1}{r} \frac{\partial \psi}{\partial \theta}, \quad u_{\theta}=-\frac{\partial \psi}{\partial r}
$$

where $\psi$ satisfies the biharmonic equation

$$
\Delta \Delta \psi=0
$$

with $\Delta=\frac{\partial^{2}}{\partial r^{2}}+\frac{1}{r} \frac{\partial}{\partial r}+\frac{1}{r^{2}} \frac{\partial^{2}}{\partial \theta^{2}}$ is the Laplace operator in the polar coordinates $(r, \theta)$.
The boundary conditions for equation (2) are either

$$
\begin{aligned}
& \psi=0, \quad \frac{\partial \psi}{\partial \theta}=0 \quad \text { at } \theta=0, \pi, \quad 0 \leq r \leq a \\
& \psi=0, \quad \frac{\partial \psi}{\partial r}=-V \quad \text { at } r=a, \quad 0 \leq \theta \leq \pi .(3) \\
& \text { or } \\
& \psi=0, \quad \frac{\partial \psi}{\partial \theta}=U r \quad \text { at } \theta=0, \quad 0 \leq r \leq a \\
& \psi=0, \quad \frac{\partial \psi}{\partial \theta}=-U r \quad \text { at } \theta=\pi, \quad 0 \leq r \leq a \\
& \psi=0, \quad \frac{\partial \psi}{\partial r}=0 \quad \text { at } r=a, \quad 0 \leq \theta \leq \pi
\end{aligned}
$$

\section{METHOD OF SOLUTION}

The biharmonic equation (2) for both boundary conditions (3) and (4) admits exact solution which can be obtained by means of bipolar coordinates. The bipolar coordinate system $(\xi, \eta)$ is introduced according the relation

$$
x+\mathrm{i} y=a \mathrm{i} \operatorname{ctg} \frac{\xi+\mathrm{i} \eta}{2},
$$

so that the two poles of the coordinates are located on the $x$-axes at the points $( \pm a, 0)$. Then

$$
x=r \cos \theta=J \operatorname{sh} \eta, \quad y=r \sin \theta=J \sin \xi,
$$

with $J=a /(\operatorname{ch} \eta-\cos \xi)$, and the semicircle $0 \leq r \leq$ $a, 0 \leq \theta \leq \pi$ in polar coordinates transforms into the strip $-\infty \leq \eta \leq \infty, \pi / 2 \leq \xi \leq \pi$ in the bipolar coordinates.

The biharmonic equation (2) in the bipolar coordinates can be rewritten as

$$
\frac{\partial^{4} \Psi}{\partial \xi^{4}}+2 \frac{\partial^{4} \Psi}{\partial \xi^{2} \partial \eta^{2}}+\frac{\partial^{4} \Psi}{\partial \eta^{4}}+2 \frac{\partial^{2} \Psi}{\partial \xi^{2}}-2 \frac{\partial^{2} \Psi}{\partial \eta^{2}}+\Psi=0
$$


for the auxiliary function $\Psi=\psi / J$

By means of equality

$$
\frac{\partial \Psi}{\partial \xi}=\frac{1}{J} \frac{\partial \psi}{\partial \xi}+\psi \frac{\partial(1 / J)}{\partial \xi}=\frac{\partial \psi}{\partial n_{\xi}}+\psi \frac{\sin \xi}{a},
$$

(where $n_{\xi}$ denotes the outer normal to the line $\xi=$ const) we can reformulate the boundary conditions (3) in terms of $\Psi$ as

$$
\begin{aligned}
& \Psi=0, \quad \frac{\partial \Psi}{\partial \xi}=0 \quad \text { at } \quad \xi=\frac{1}{2} \pi, \quad|\eta| \leq \infty \\
& \Psi=0, \quad \frac{\partial \Psi}{\partial \xi}=V \quad \text { at } \quad \xi=\pi, \quad|\eta| \leq \infty .
\end{aligned}
$$

By choosing a solution of equation (7)

$$
\Psi=A \sin \xi+B \cos \xi+C \xi \sin \xi+D \xi \cos \xi,
$$

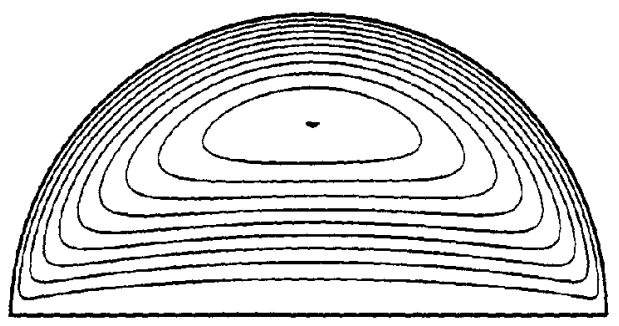

we can satisfy all boundary conditions (8), provided that the values of the constants $A, B, C, D$ are:

$$
\begin{aligned}
& A=\frac{2 \pi}{\pi^{2}-4} V, \quad B=-\frac{2 \pi^{2}}{\pi^{2}-4} V, \\
& C=-\frac{4}{\pi^{2}-4} V, \quad D=\frac{2 \pi}{\pi^{2}-4} V .
\end{aligned}
$$

Returning from $\Psi(\xi)$ in (9) to the stream function $\psi(r, \theta)$ by means of equalities

$$
\begin{gathered}
J \sin \xi=r \sin \theta, \quad J \cos \xi=\frac{r^{2}-a^{2}}{2 a}, \\
\xi=\pi-\operatorname{arctg} \frac{2 a r \sin \theta}{a^{2}-r^{2}},
\end{gathered}
$$

after some reductions, we come to the expression

$$
\begin{array}{r}
\psi=\frac{2 V}{\pi^{2}-4}\left[\frac{\pi\left(a^{2}-r^{2}\right)+4 a r \sin \theta}{2 a} \times\right. \\
\left.\times \operatorname{arctg} \frac{2 a r \sin \theta}{a^{2}-r^{2}}-\pi r \sin \theta\right] .
\end{array}
$$

The behaviour of the stream function $\psi$ near the corner point $r_{c}=a, \theta_{c}=0$ can be obtained from expansion into Taylor series the expression (12) in the local polar coordinates $(\rho, \chi)$ with $r \cos \theta=a-$ $\rho \sin \chi, r \sin \theta=\rho \cos \chi$. The first linear on $\rho$ term is:

$$
\psi_{\mathrm{loc}}=\frac{4 V \rho}{4-\pi^{2}}\left(\chi \cos \chi+\frac{1}{2} \pi \chi \sin \chi-\frac{\pi^{2}}{4} \sin \chi\right),
$$

which corresponds to the Goodier [1] - Taylor [10] solution for a quarter plane $\rho \geq 0,0 \leq \chi \leq \pi / 2$ with the constant tangential velocity $-V$ applied at the plane $\chi=0$.

The exact solution of (2) for the boundary conditions (4) can be derived in a similar way,

$$
\begin{aligned}
\psi=- & \frac{2 U}{\pi^{2}-4}\left[\frac{\pi a r \sin \theta+a^{2}-r^{2}}{a} \times\right. \\
& \left.\times \operatorname{arctg} \frac{2 a r \sin \theta}{a^{2}-r^{2}}-\frac{1}{2} \pi^{2} r \sin \theta\right] .
\end{aligned}
$$

Fig. 1. Streamline pattern of the Stokes flow in a semicircle according to exact solution (12). The streamlines are plotted for the contour lavels $\psi_{n}=0.015 \mathrm{Va} \mathrm{n}$ with $n=1, \ldots, 10$. The maximum value of the stream function at the stagnation point is $0.1713 \mathrm{Va}$.

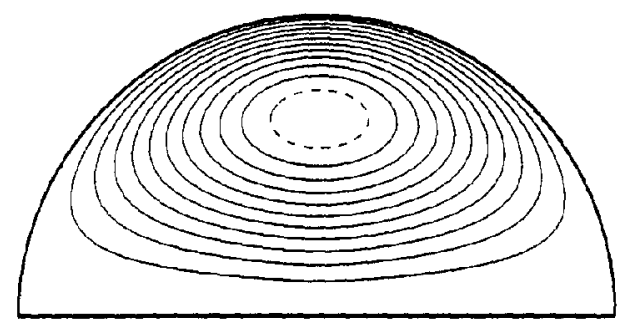

Fig. 2. Streamline pattern of the Stokes flow in a semicircle according to approximate solution (14). The streamlines are plotted for the contour lavels $\tilde{\psi}_{n}=0.015 \mathrm{Van}$ with $n=1, \ldots, 10$.

\section{RESULTS AND DISCUSSION}

Fig. 1 shows a streamline pattern for the flow described by equation (12). The flow forms a single vortex cell which has one stagnation elliptic point $r_{e}=0.636 a, \theta_{e}=\pi / 2$.

It was reported $[5,6]$ that the approximate solution of the problem (2), (3) is

$$
\tilde{\psi}=\frac{4 V a}{3 \gamma}\left(\frac{r}{a}\right)^{2}\left[1-\left(\frac{r}{a}\right)^{\gamma}\right] \sin ^{2} \theta,
$$

with $\gamma=(11 / 3)^{\frac{1}{2}}-1=0.915$. It is worth noting that this solution does not satisfy both the governing biharmonic equation (2) for the stream function and the non-slip conditions (3) at the moving boundary. However, the streamline pattern presented in Fig. 2 (see also Fig. 8.2.3 in [9]) for the approximate solution (14) has qualitatively similar appearence with Fig. 1.

Fig. 3 represents a distribution of the tangential velocity $u_{\theta}$ along the middle line $\theta=\pi / 2$ of the cavity. Again, we see a reasonable quantitative corre- 


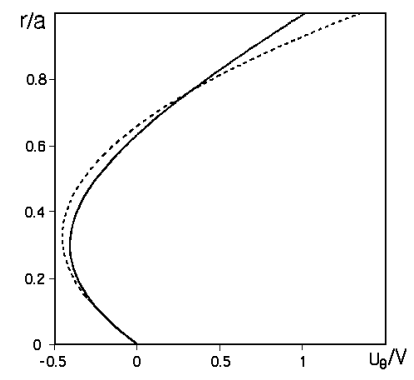

Fig. 3. Cross-sectional distribution of the tangential velocity $u_{\theta}$ along the line $\theta=\pi / 2$ for exact solution (12), solid line, and approximate solution (14), dashed line.

spondence between exact and approximate solutions in the centre of the cavity. One should note the essential difference between velocities at the curved boundary: the approximate solution provides the value $1.333 \mathrm{~V}$ instead of the prescribed value $V$. Besides, the approximate solution underestimates significantly the velocity near the corner points: at the boundary $r=a$ the tangential velocity $u_{\theta}$ varies as $\frac{4}{3} V \sin ^{2} \theta$ instead of being constant. These discrepancies may have a crucial importance for a quantitative study of mixing process in such a cavity.

\section{CONCLUSION}

Thus, usage of the bipolar coordinates provides exact analytical solution for Stokes flow in a semicircle induced by uniform tangential velocities at the boundary. Such solution seems to be important for accurate analysis of mixing process in the partitioned-pipe mixer [5, 6, 9].

For a nonuniform velocity distribution along the boundaries the exact solution can be constructed in a form of some integrals. In particular, the case when nonzero constant tangential velocity is applied at the boundary $r=a$ with $\theta_{0} \leq \theta \leq \pi-\theta_{0}$ is particularly interesting because it can provide both an analytical expression of the amplitudes of the Moffatt eddies in a finite cavity and a clear picture of the competition befween local and far-field effects for dominance in the neighbourhood of the corner points.

1. Goodier J. N. An analogy between the slow motion of a viscous fluid in two dimensions, and systems of plane stress // Phil. Mag. (Ser. 7).- 1934.- 17.P. 554-564.

2. Jeffery G. B. Plane stress and plane strain in bipolar co-ordinates // Phil. Trans. R. Soc. London.- 1920.ser A 221.- P. 265-293.

3. Жуковский Н. Е. О движении вязкой жидкости, зак.юченной между двумя врашаюшимися эксцентричными цилиндрическими поверхностями // Сообщ. Харьков-го матем. общ-ва при Харьков. Ун-те.- 1887.- Вып 1.- С. 31-46. Также: ЖKуковский H. Е. Полное собрание сочинений, том IV, 250-278, М.-Л.: ОНТИ, 1937. Также: ККуковский Н. Е. Собрание сочинений, том III, 121-132, М.-Л.: ГИТТЛ, 1949.

4. Жуковский Н. Е., Чаплыгин С. А. О трении смазочного слоя между шипом и подшипником // Труды отд. физ. наук Обш-ва любит. естествознания.1906.- 13, No 1.- С. 24-33. Также: Жуковский H. E. Полное собрание сочинений, том IV, 279-319, М.-Л.: ОНТИ, 1937. Также: Ж Жковский H. Е. Собрание сочинений, том III, 133-151, М.-Л.: ГИТТЛ, 1949. Также: Чаплыгин С. А. Полное собрание сочинений, том II, 91-106, Л.: АН СССР, 1933. Также: Чаплыгин С. А. Собрание сочинений, том III, 7-26, М.-Л.: ГИТТЛ, 1950.

5. Khakhar D. V., Franjione J. G., Ottino J. M. A case study of chaotic mixing in deterministic flows, the partitioned-pipe mixer // Chem. Engng. Sci.- 1987.42.- P. 2909-2919.

6. Kusch H. A., Ottino J. M. Experiments on mixing in continuous chaotic flows // J. Fluid Mech.- 1992.236.- P. 319-357.

7. Müller W. Ebene Spannungs- und Strömungsfelder mit zwei kreiszylindrischen Grenzen // Ing. Archiv.1942.- 13.- S. 37-58.

8. Müller, $W$. Beitrag zur Theorie der langsamen Drehung zweier exzentrischer Kreiszylinder in der zähen Flüssigkeit // Z. angew. Math. Mech.- 1942.22.- S. 177-189.

9. Ottino J. M. The Kinematics of Mixing: Stretching, Chaos and Transport.- Cambridge: Cambridge University Press, 1989.- $364 \mathrm{p}$.

10. Taylor G. I. On scraping viscous fluid from a plane surface // Miszellangen der Angewandten Mechanik (Festschrift Walter Tollmien).- Berlin, AkademieVerlag, 1962.- P. 313-315. 